\title{
Genetic identification of non-specific esterases of the mouse cauda epididymidis and description of esterase-28, a new carboxylesterase isoenzyme (EC 3.1.1.1)
}

\author{
O. von Deimling and B. Wassmer \\ Pathologisches Institut, Abteilung für Chemische Pathologie, Universität Freiburg, Albertstraße 19, \\ D-7800 Freiburg, FRG
}

\begin{abstract}
Summary. Twenty-five (25) electrophoretic bands with esterase activity were distinguished in supernatants of cauda epididymidis of DBA/2J mice. Twenty (20) of these were assigned to 10 genetically defined esterases (ES-1, ES-2, ES-3, ES-6, ES-7, ES-11, ES-14, ES-17, ES-19, ES-22) which were already known from investigations of other mouse tissues. Furthermore, ES-10 was identified in cauda supernatants after isoelectric focussing. A hitherto genetically undefined esterase was assigned to locus $E s-28$ which was expressed solely in the epididymis. Three phenotypes were distinguished: ES-28A was present in the majority of the inbred strains examined, ES-28B was observed in AKR/Han mice and ES-28C was found in SEG/1 mice.
\end{abstract}

Keywords: esterase; mouse; cauda epididymidis

\section{Introduction}

Previous electrophoretic studies revealed a multiplicity of non-specific esterases present in the epididymal tissue of the house mouse (Allen \& Slater, 1957; Allen \& Hunter, 1960; Ruddle \& Harrington, 1967). A differential response to castration and dependence of certain esterase bands upon testosterone has also been demonstrated. Attention has been drawn to the fact that the esterases of the caput and cauda epididymidis are markedly different from each other; some of them are found neither in testis nor in serum. Of 18 epididymal esterase bands distinguished electrophoretically using $\alpha$ - or $\beta$-naphthyl acetate as substrate, 14 occurred in the caput and 12 in the cauda (Abou-Hailla \& Fain-Maurel, 1986, 1987). By examining the response to various inhibitors the majority of epididymal esterases were assigned to the carboxylesterase group EC 3.1.1.1 (Abou-Haïla \& Fain-Maurel, 1986).

Characterization of non-specific esterases merely by their electrophoretic mobility and by use of only one type of substrate such as $\alpha$-naphthyl acetate gives insufficient information on the actual numbers of enzymes which give rise to the complex electrophoretic banding pattern. Multiplicity of bands may be produced by allelic variation, by post-translational modification, and by multiplicity of the structural genes themselves. In the past, the genetic characterization of esterases by the structural locus and the allelic type has proved to be the preferred method for unambiguous identification of any mouse esterase. Therefore, in the present report, the non-specific esterases of the mouse cauda epididymidis were re-examined and assigned to the genetic nomenclature (Peters, 1982) as far as possible.

\section{Materials and Methods}

Animals. The esterases of the cauda epididymidis were examined in mice of strain DBA/2J and in 9 other reference strains which were known to differ in their allelic esterase pattern (Table 1). The mice were kept at the Institute of 
Pathology: 2 strains were only partly inbred (MOLH (F19) was derived from wild M. m. molossinus and SEG/I (FI0) was derived from wild $M$. spretus), but both were homozygous with respect to cauda esterases.

Preparation of samples. Each cauda epididymidis was removed from about 5 or 6 animals, then pooled, homogenized in a 7 -fold $(\mathrm{w} / \mathrm{v})$ volume of aqueous Triton X-100 $(0.2 \% \mathrm{w} / \mathrm{v})$ and centrifuged $\left(100000 \mathrm{~g} ; 45 \mathrm{~min} ; 2^{\circ} \mathrm{C}\right)$. For controls, liver, kidney, small intestine, lung, submandibular gland, thymus, spleen, skeletal muscle, testis, seminal vesicle and brain were prepared in the same way except that specimens were not pooled. Red blood cells were washed three times in $0.9 \%(\mathrm{w} / \mathrm{v}) \mathrm{NaCl}$ and lysed in a 3 -fold volume of aqueous $0.2 \%$ Triton X-100. All supernatants and the plasma were stored at $-70^{\circ} \mathrm{C}$ until required.

Separation of esterases. Vertical polyacrylamide electrophoresis (PAGE) was carried out on slab gels $(135 \times 90 \times 1 \mathrm{~mm})$. Separation gel $(7.3 \%)$ and spacer gel $(3 \cdot 1 \%)$ were produced as described by Lipps et al. (1979) using the imidazole/glycylglycine buffer system $\mathrm{pH} 7 \cdot 4$. Isoelectric focussing (IEF) was performed on $5 \%$ slab gels (LKB, Bromma, Sweden), pH 4.0-6.5, using the LKB equipment.

Staining methods. The gels were stained for esterase using one of 9 different substrates: (1) 5-bromoindoxyl acetate (5Brl-0-2); (2) $\alpha$-naphthyl acetate $(\alpha \mathrm{N}-0-2)$; (3) $\alpha$-naphthyl butyrate $(\alpha \mathrm{N}-0-4)$; (4) naphthol AS-D acetate (NASD-0-2); (5) naphthol AS-D butyrate (NASD-0-4); (6) indoxyl butyrate (I-0-4); (7) 4-methylumbelliferyl acetate (U-0-2); (8) 4-methylumbelliferyl butyrate (U-0-4); (9) N-acetyl-L-alanine- $\alpha$-naphthyl ester $(\alpha \mathrm{N}-0$-ala). The substrates differ by their alcohol or acid moiety and are suitable for distinguishing between certain groups of esterases, such as carboxylesterases (EC 3.1.1.1), acetylesterases (EC 3.1.1.6) and others (von Deimling et al., 1983). For inhibition studies, the gels were incubated before staining in 66-mM-phosphate buffer, pH 7-3, containing $200 \mu \mathrm{M}$-his-pnitrophenyl phosphate (BNPP), $10 \mu \mathrm{m}$-diisopropyl fluorophosphate (DFP), I mM-eserine, or $1 \mathrm{~mm} p$-chloromercuri phenylsulphonate $(p C M P S)$ for $30 \mathrm{~min}$. The first 3 inhibitors are acylating; they differ by their charge and show, therefore, a discriminating inhibitory efficiency against serine esterases such as cholinesterases (EC 3.1.1.8) and others. The latter inhibitor reacts with -SH groups and is directed against arylesterases (EC 3.1.1.2).

\section{Results}

\section{Identification of epididymal esterases}

Supernatants of cauda epididymidis of the 10 reference strains (Table 1) were separated electrophoretically and then stained for esterase using different substrates and inhibitors as outlined in the legends to the figures. Strain-specific esterase banding patterns were obtained for each strain, depending on their different alleles. DBA/2J was chosen for documentation of esterases because the phenotypes expressed in this strain are widely distributed among inbred strains of laboratory mice. At least 25 bands or esterase-active zones were distinguished in strain DBA/2J. They were labelled by arabic numerals as shown in Fig. 1 . The 25 esterase bands were identified as components of 14 separate esterases according to the following criteria: (a) staining pattern using different substrates combined with different inhibitors (Fig. 1); (b) comparison with the distribution of bands in other tissues, such as lung, kidney, thymus or testis; (c) distribution pattern among the reference strains listed in Table 1.

The actual interpretation of the nature of the 25 bands is as follows (Table 2). Bands 1, 2 and 3 showed identical staining and inhibitory properties and, consequently, are considered to represent 3 forms of one enzyme. This enzyme is variant in SEG/1 and provisional findings indicate that it is coded for by a gene locus on chromosome 8 . This enzyme was provisionally termed 'not identified cauda esterase I' (CDE-I) and was not further investigated (Fig. 2f).

Band 4 stained well with I-0-4 (Fig. 2a) and was partly inhibited by BNPP (Fig. 2d). It corresponds to $E_{1}$ of Abou-Haïla \& Fain-Maurel (1987). The genetic variation in the test strains clearly indicated that Band 4 was identical with ES-6A ${ }^{3}$, the trimeric form of ES-6A (Nash \& von Deimling, 1982). Likewise, Band 6 was identified as the monomeric form ES-6A ${ }^{1}$.

Band 5 exhibited properties similar to those of Bands 7, 9, 10,11 and 12: these 6 esterases were resistant to inhibition by $10 \mu \mathrm{M}-\mathrm{DFP}$ and $1 \mathrm{~mm}-p \mathrm{CMPS}$. They stained well with acetates such as $\alpha \mathrm{N}-0-2$ (Fig. 2f) and 5Brl-0-2 (Fig. 2g), and less well with NASD-0-2 (Fig. 2d), but they failed to cleave butyrates at a significant rate (Fig. 2a, c, e). They were considered to represent different forms of one enzyme. Band 11, the strongest band of this series, was identified as ES-17A. Hence, it was concluded that in the cauda epididymidis ES-17 is expressed as a cascade of bands with $R_{\mathrm{m}}$ values between 17.9 and $36 \cdot 1$ (Table 2). 
Table 1. Alleles* at 12 esterase loci in a set of 10 reference strains of mouse used for identification of cauda esterases

\begin{tabular}{|c|c|c|c|c|c|c|c|c|c|c|}
\hline & AKR/Han & $\mathrm{BALB} / \mathrm{cJ}$ & $\mathrm{C} 57 \mathrm{BL} / 6 \mathrm{~J}$ & $\mathrm{DBA} / 2 \mathrm{~J}$ & IS/Cam & MOLH & PUC/1 & $\mathrm{PWD} / \mathrm{Ph}$ & $\mathrm{SEG} / 1$ & SK/Cam \\
\hline ES-1 & b & b & a & b & $\mathrm{i}$ & f & b & a & $\mathrm{g}$ & b \\
\hline ES-2 & b & b & b & b & b & d & b & $\mathrm{h}$ & $\stackrel{o}{j}$ & $\mathrm{a}$ \\
\hline ES-3 & c & a & a & c & b & b & b & b & b & $\mathrm{c}$ \\
\hline ES-6 & a & a & a & a & $\mathrm{a}$ & e & b & a & a & a \\
\hline ES-7 & b & b & b & b & b & $\mathrm{e}$ & d & b & $\mathrm{f}$ & b \\
\hline ES-10 & b & $\mathbf{a}$ & a & b & a & b & b & c & a & b \\
\hline ES-11 & $\mathrm{a}$ & a & $\mathrm{a}$ & a & b & c & b & $c$ & f & b \\
\hline ES-14 & $\mathrm{r}$ & $r$ & $r$ & $r$ & $r$ & $r$ & $r$ & $r$ & 1 & $r$ \\
\hline ES-17 & a & a & $\mathrm{a}$ & a & a & b & a & b & $\mathrm{c}$ & $\mathrm{a}$ \\
\hline ES- 19 & $\mathrm{a}$ & a & a & a & a & a & a & a & a & a \\
\hline ES-22 & d & d & d & d & $\mathrm{c}$ & a & $\mathrm{e}$ & $\mathrm{i}$ & f & d \\
\hline ES-28† & $\mathrm{b}$ & a & $\mathrm{a}$ & a & a & $\mathrm{a}$ & $\mathrm{a}$ & a & $\mathrm{c}$ & a \\
\hline
\end{tabular}

*Britton-Davidian \& Bonhomme (1979); Chapman et al. (1979); Hilgers et al. (1988); Medda et al. (1986); von Deimling, (1984); von Deimling et al. (1988).

†Allele distribution according to this study.

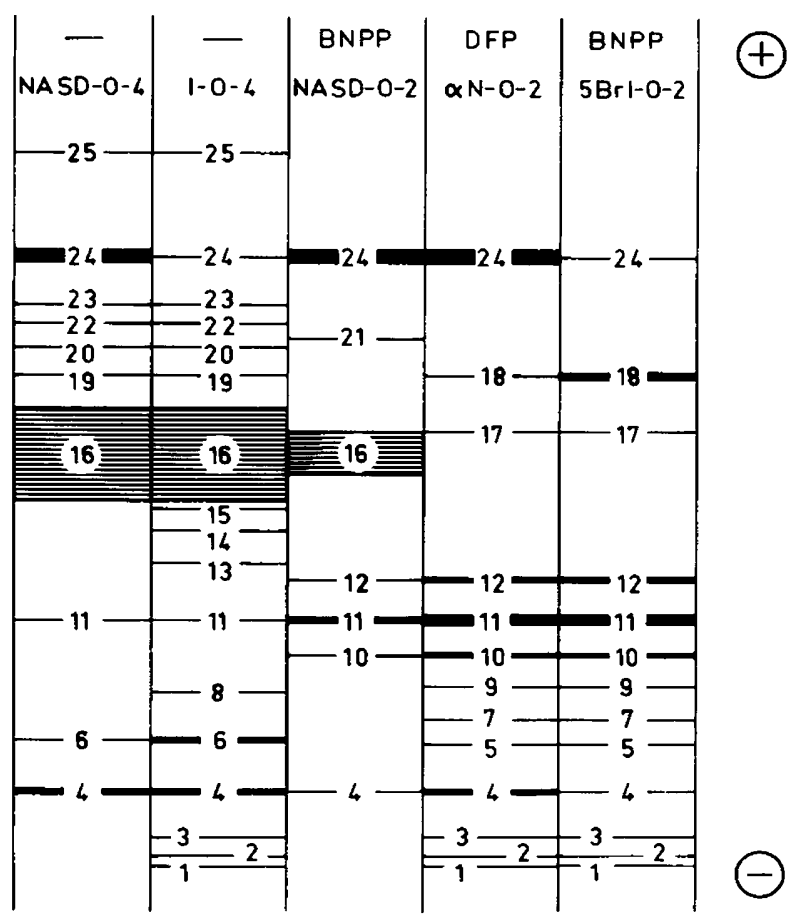

Fig. 1. Scheme of esterase bands of the cauda epididymidis of DBA/2J mice obtained after disc electrophoresis $(7 \cdot 3 \%$ polyacrylamide, imidazole buffer $\mathrm{pH} 7 \cdot 4)$ and subsequent staining using 5 different substrates (NASD-0-4, I-0-4, NASD-0-2, $\alpha \mathrm{N}-0-2,5 \mathrm{BrI}-0-2)$ combined with two different inhibitors $(200 \mu \mathrm{M}$-BNPP, $10 \mu \mathrm{M}$-DFP).

Band 8 stained well with I-0-4 (Fig. 2a) and $\alpha \mathrm{N}-0$-ala (not shown), but did not hydrolyse NASD-0-2. Treatment of the gel with $1 \mathrm{~mm}-p$ CMPS resulted in complete inhibition. Band 8 was variant in SEG/1 and was identified as ES-14R. 


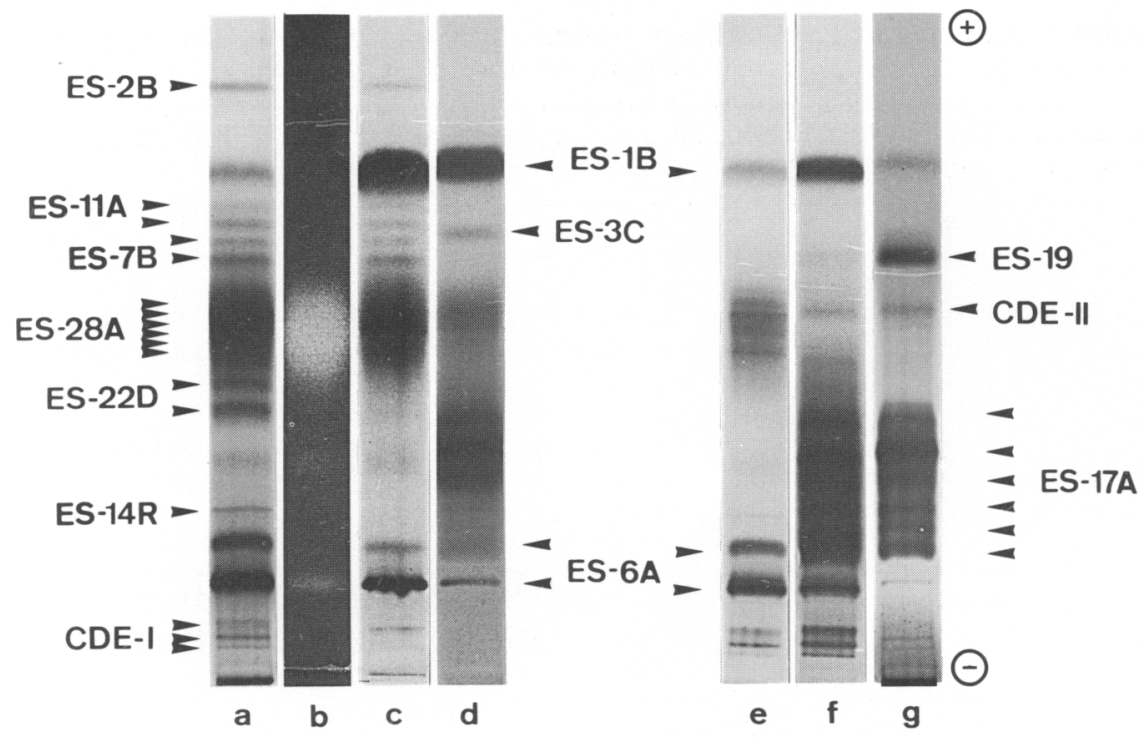

Fig. 2. Esterase banding patterns of the cauda epididymidis of DBA/2J mice after disc electrophoresis $(7 \cdot 3 \%$ polyacrylamide, imidazole buffer $\mathrm{pH} 7 \cdot 4)$, depending on inhibitors and substrates. The amount of supernatant, inhibitor, substrate, incubation period and temperature were as follows: (a) $7 \cdot 5 \mu \mathrm{l}$, no inhibitor, I-0-4/NBT, $15 \mathrm{~min}, 40^{\circ} \mathrm{C}$; (b) $12 \mu \mathrm{l}$, no inhibitor, U-0-2, $2 \mathrm{~min}, 40^{\circ} \mathrm{C}$; (c) $12 \mu \mathrm{l}$, no inhibitor, NASD-0-4, $90 \mathrm{~min}, 40^{\circ} \mathrm{C}$; (d) $10 \mu \mathrm{l}, 200 \mu \mathrm{M}$-BNPP, NASD$0-2,90 \mathrm{~min}, 40^{\circ} \mathrm{C}$; (e) $10 \mu 1,200 \mu \mathrm{M}-\mathrm{BNPP}, \alpha \mathrm{N}-0-4,60 \mathrm{~min}, 40^{\circ} \mathrm{C}$; (f ) $7 \cdot 5 \mu \mathrm{l}, 10 \mu \mathrm{M}-\mathrm{DFP}, \alpha \mathrm{N}-0-$ $2,60 \mathrm{~min}, 20^{\circ} \mathrm{C}$; (g) $10 \mu \mathrm{l}, 200 \mu \mathrm{M}-\mathrm{BNPP}, 5 \mathrm{BrI}-0-2,50 \mathrm{~min}, 40^{\circ} \mathrm{C}$.

Bands 13, 14 and 15 showed similar staining properties, being inactive against U-0-2 (Fig. 2 b) and NASD-0-4 (Fig. 2c), but active against I-0-4 (Fig. 2a) and highly sensitive to inhibition by BNPP. They were considered to be 3 forms of one enzyme. The genetic variation in the test strains indicates that this enzyme was ES-22D.

Band 16 was a broad zone of esterase activity showing microheterogeneity. It corresponded to a new esterase which was absent from other mouse organs. It was termed ES-28 (Fig. 2a, b) and biochemically characterized as outlined below.

Band 17 was resistant to inhibition by organophosphates. It was stainable with acetyl esters as substrates, such as $\alpha \mathrm{N}-0-2$ and 5BrI-0-2 (Fig. 2f, g). Because of overlapping by ES-28 we could not decide whether Band 17 also reacted with butyrates. Band 17 was provisionally termed 'not identified cauda esterase II' (CDE-II) and was not further investigated.

Band 18 appeared as a strong band after inhibition with BNPP and subsequent staining using $5 \mathrm{BrI}-0-2$ as substrate. It did not hydrolyse NASD-0-2 and was inhibited by 1 mM- $p$ CMPS (not shown). Band 18 was invariably present in all strains examined and was identified as ES-19 (Fig. $2 \mathrm{~g}$ ), an arylesterase (EC 3.1.1.2) discovered previously in testis and brain (Münz \& von Deimling, 1985).

Bands 19 and 20 showed similar staining properties, being active towards I-0-4, $\alpha$ N-0-4 (Fig. $2 \mathrm{a}, \mathrm{b}$ ) and $\alpha \mathrm{N}-0$-ala (not shown). Both bands were inhibited by BNPP or DFP. It was concluded that Bands 19 and 20 corresponded to 2 forms of a single enzyme. The variation of this enzyme among our reference strains indicated that it was identical with ES-7B.

Band 21 showed a weak activity against NASD-0-2. It was resistant to inhibition by BNPP (Fig. $2 \mathrm{~d}$ ), but sensitive to eserine (not shown). By comparing our reference strains it transpired that Band 21 was identical with ES-3C.

Bands 22 and 23 represented another pair of bands showing similar properties against substrates and inhibitors. These bands were active towards I-0-4 and NASD-0-4 (Fig. 2a, c) but were not active 
Table 2. $R_{\mathrm{m}}$ values of 25 esterase-active electrophoretic bands (7.3\% polyacrylamide, imidazole buffer $\mathrm{pH} 7 \cdot 4$ ) of the DBA/2J mouse cauda epididymidis and their assignment to genetically defined enzymes

\begin{tabular}{|c|c|c|c|}
\hline Band no. & $R_{\mathrm{m}}(\%)^{*}$ & Phenotype & References \\
\hline 1 & $5 \cdot 1)$ & & \\
\hline 2 & $6 \cdot 1\}$ & [CDE-I] & This study \\
\hline 3 & $8 \cdot 2)$ & & Petras \& Sinclair (1969); \\
\hline $\begin{array}{l}4 \\
5\end{array}$ & $\begin{array}{l}12.9 \\
17.9\end{array}$ & $\begin{array}{l}\text { ES-6A } \\
\text { FS-17A }\end{array}$ & Nash \& von Deimling (1982) \\
\hline $\begin{array}{l}5 \\
6\end{array}$ & $\begin{array}{l}17.9 \\
18.4\end{array}$ & ES-6 $A^{1}$ & \\
\hline 7 & $20 \cdot 9$ & ES-17A & \\
\hline 8 & $24 \cdot 0$ & ES-14R & Britton-Davidian \& Bonhomme (1979) \\
\hline 9 & $24 \cdot 3)$ & & \\
\hline 10 & $27 \cdot 6$ & & Otto \& von Deimling (1983) \\
\hline 11 & 31.5 & $\mathrm{ES}-1 / \mathrm{A}$ & Utto \& von Deimling (1983) \\
\hline 12 & $36 \cdot 1)$ & & \\
\hline 13 & $37.8 ?$ & & \\
\hline 14 & $41 \cdot 3$ & ES-22D & Eisenhardt \& von Deimling (1982) \\
\hline 15 & $43.9)$ & & \\
\hline 16 & $44 \cdot 4-55 \cdot 0$ & ES-28A & This study \\
\hline 17 & $52 \cdot 0$ & {$[\mathrm{CDE}-\mathrm{II}] \dagger$} & \\
\hline 18 & $58 \cdot 2$ & ES-19 & Münz \& von Deimling (1985) \\
\hline $\begin{array}{l}19 \\
20\end{array}$ & $\left.\begin{array}{l}58 \cdot 2 \\
61 \cdot 2\end{array}\right\}$ & ES-7B & Lipps et al. (1979) \\
\hline 21 & $62 \cdot 2$ & ES-3C & Ruddle \& Roderick (1965) \\
\hline 22 & $\left.\begin{array}{l}63 \cdot 8 \\
65 \cdot 8\end{array}\right\}$ & ES-11A & Peters \& Nash (1977) \\
\hline $\begin{array}{l}23 \\
24\end{array}$ & $\begin{array}{l}65 \cdot 8\} \\
70.4\end{array}$ & ES-1B & Popp \& Popp (1962) \\
\hline 25 & $82 \cdot 1$ & ES-2B & Petras (1963) \\
\hline
\end{tabular}

$* \%$ Mobility of the bromophenol blue front $(=100)$.

$\div$ Brackets: provisional designations.

against $\alpha \mathrm{N}-0$-ala (not shown). The esterase activity of these bands was abolished after inhibition with BNPP (Fig. 3a, b) or eserine (not shown). The variation among our reference strains indicated that Bands 22 and 23 were 2 forms of ES-11A.

Band 24 stained strongly with all substrates used and was slightly inhibited by organophosphates (Fig. 3a, b). It was identical with Band E15 described by Abou-Haïla \& Fain-Maurel (1986) and with Band IV-20 identified by Ruddle \& Harrington (1967). It was identified as ES-1B (Fig. 2c, $d, f)$.

Band 25 was very sensitive to inhibition by organophosphates (Fig. 3a, b) and stained well with various acetate or butyrate esters. It was identical with Band V-10 of Ruddle \& Harrington (1967) and was identified as ES-2B (Fig. 2a, c).

\section{Characterization of ES-28 by disc electrophoresis}

ES-28 showed phenotypic variation in the strains examined. The phenotype found in BALB/cJ, C57BL/6J, DBA/2J, IS/Cam, MOLH, PUC/1Fre, PWD/Ph and SK/Cam mice was designated ES28A. ES-28A appeared as a single band, surrounded by a broad diffuse zone of esterase activity if NASD-0-4 was used as substrate (Fig. 2c, 3a). It was also well demonstrated by using U-0-2 (Fig. 2b), U-0-4 (not shown), I-0-4 (Fig. 2a), $\alpha \mathrm{N}-0-4$ (not shown) and other chromogenic esters as substrates but it did not catalyse the hydrolysis of $\alpha \mathrm{N}-0$-ala.

In many strains, ES-28A co-migrated with the anodal bands of ES-22D which is relatively strongly expressed in the cauda epididymidis. Since ES-22 stains neither with NASD-0-4 nor 

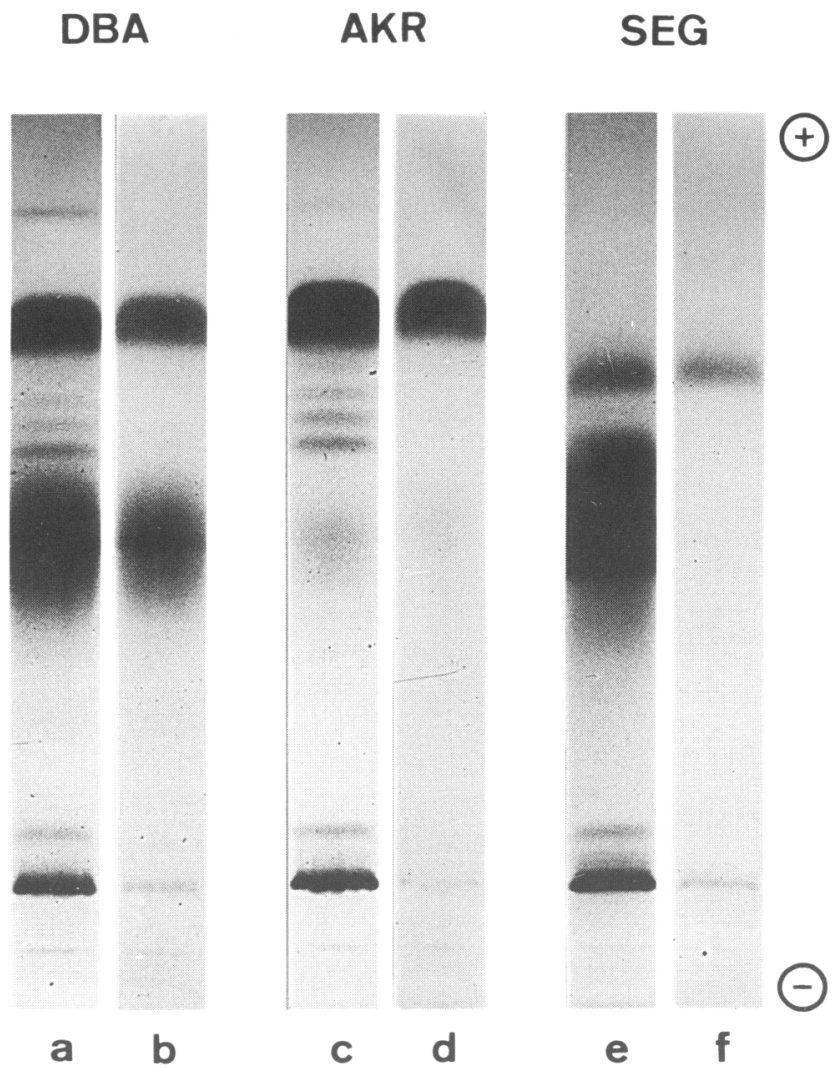

Fig. 3. Esterase banding patterns of the cauda epididymidis of 3 different strains of mice (DBA/ $2 \mathrm{~J}$, AKR/Han, SEG/1) after disc electrophoresis $(7 \cdot 3 \%$ polyacrylamide, imidazole buffer $\mathrm{pH}$ 7.4). For each lane, $12 \mu \mathrm{l}$ supernatant were applied, the substrate was NASD-0-4 and the incubation period was $90 \mathrm{~min}$ at $40^{\circ} \mathrm{C}(\mathrm{a}, \mathrm{c}, \mathrm{e})$. Without inhibition $(\mathrm{b}, \mathrm{d}, \mathrm{f})$ gels were incubated in $200 \mu \mathrm{M}$-BNPP before staining.

with U-0-2, both substrates are useful for demonstrating ES-28A alone and distinguishing it from ES-22. If, however, I-0-4, $\alpha \mathrm{N}-0-2$ or $\alpha \mathrm{N}-0-4$ were used as substrates, ES-28A and ES-22D overlapped each other (Fig. 2a). ES-28A was weakly inhibited by $200 \mu \mathrm{M}-\mathrm{BNPP}$ and the central band mentioned above was better seen with, rather than without, inhibition (Fig. 3b). It was totally inhibited by $10 \mu \mathrm{M}$-DFP, whereas $p$ CMPS had no effect upon its activity. We therefore classify ES-28 with the carboxylesterases (EC 3.1.1.1). ES-28 was expressed in the cauda epididymidis and, to a lesser degree, in the caput epididymidis. It could not be detected in liver, kidney, small intestine, skeletal muscle, lung, thymus, submandibular gland, spleen, testis, seminal vesicle, brain, erythrocytes or serum.

The phenotype observed in AKR/Han mice was designated ES-28B. ES-28B co-migrated with ES-28A but showed only very weak activity (Fig. 3c). It was, like ES-28A, only weakly inhibited by $200 \mu \mathrm{M}$-BNPP (Fig. 3d).

A third phenotype designated ES-28C was found in SEG/1 mice. The electrophoretic mobility of ES-28C was slightly greater than that of ES-28A (Fig. 3e). ES-28C exhibited the same substrate preference as ES-28A and ES-28B, but was extremely sensitive to inhibition by $200 \mu \mathrm{M}-\mathrm{BNPP}$ (Fig. 3f). It was therefore easier to distinguish ES-28A from ES-28C with inhibition than without. 


\section{Demonstration of ES-28 and other esterases by isoelectric focussing}

After isoelectrofocussing of cauda epididymal supernatants of DBA/2J mice and subsequent staining using $\alpha \mathrm{N}-0-2$ as the substrate, a cascade of bands was seen between ES- 1 and ES- 6 which could not be identified immediately (Fig. 4f). Further experiments showed that this cascade consisted of three major elements: ES-17A, ES-22D and ES-28A. Nine bands assigned to ES-17A were accentuated by inhibiting ES-1, ES-6, ES-22 and ES-28 with $200 \mu \mathrm{M}$-DFP before staining (Fig. $4 \mathrm{~g}$ ). ES-22D (not labelled) could not be clearly demonstrated because of overlapping by ES-28A. Its position in Fig. 4(f) is cathodal to the tetrad of ES-22F (Fig. 4e). ES-28A was demasked by inhibiting ES-22D with $1 \mathrm{mm-BNPP}$ and by using $\alpha \mathrm{N}-0-4$ as the substrate because this is not cleaved by ES-17 (Fig. 4c). ES-28A appeared as 7 discrete bands labelled 1-7 in Fig. 4(c). A similar banding pattern was seen if $\alpha \mathrm{N}-0-4$ was replaced by U-0-4, or U-0-2 (Fig. $4 \mathrm{~b}$ ) whereas NASD-0-4 and I-0-4 proved to be less useful for demonstrating ES-28A after IEF (not shown).

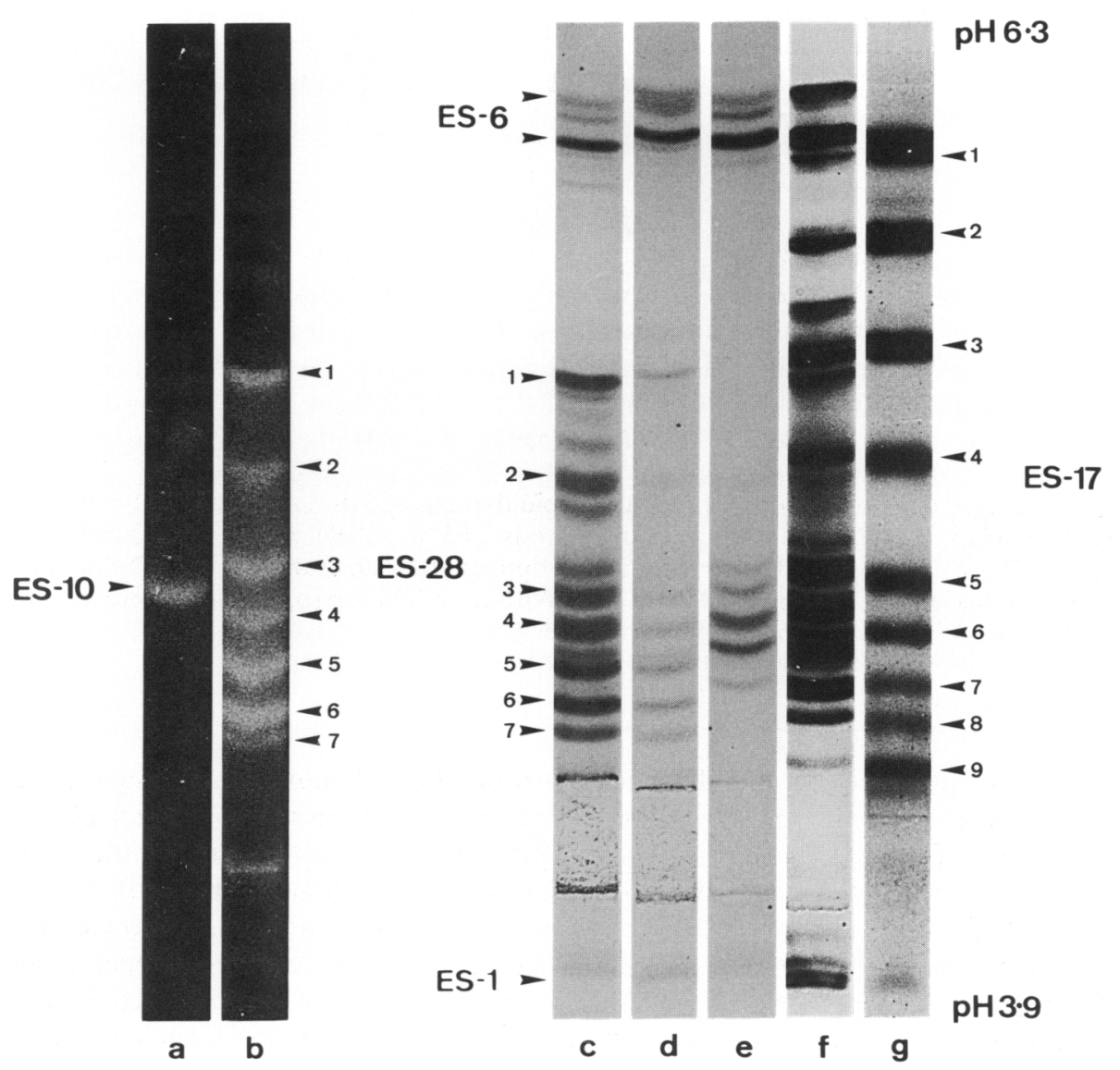

Fig. 4. Esterase banding patterns of the cauda epididymidis of different strains of mouse after isoelectric focussing $\mathrm{pH} 4 \cdot 0-6 \cdot 5$. The amount and origin of supernatants applied to each track, as well as the inhibitors, substrates, incubation period and temperature used were the following: (a) $40 \mu \mathrm{l}, \mathrm{DBA} / 2 \mathrm{~J}, 200 \mu \mathrm{M}-\mathrm{DFP}, \mathrm{U}-0-2,3 \mathrm{~min}, 25^{\circ} \mathrm{C}$; (b) $40 \mu \mathrm{l}, \mathrm{DBA} / 2 \mathrm{~J}, 200 \mu \mathrm{M}-\mathrm{BNPP}, \mathrm{U}-$ $0-2,2 \mathrm{~min}, 25^{\circ} \mathrm{C}$; (c) $15 \mu \mathrm{l}$, DBA $/ 2 \mathrm{~J}, 200 \mu \mathrm{M}-\mathrm{BNPP}, \alpha \mathrm{N}-0-4,25 \mathrm{~min}, 40^{\circ} \mathrm{C}$; (d) $15 \mu \mathrm{l}, \mathrm{AKR} / \mathrm{Han}$, $200 \mu \mathrm{M}-\mathrm{BNPP}, \alpha \mathrm{N}-0-4,25 \mathrm{~min}, 40^{\circ} \mathrm{C}$; (e) $15 \mu \mathrm{l}, \mathrm{SEG} / 1,200 \mu \mathrm{M}-\mathrm{BNPP}, \alpha \mathrm{N}-0-4,25 \mathrm{~min}, 40^{\circ} \mathrm{C}$; (f) $20 \mu \mathrm{l}, \mathrm{DBA} / 2 \mathrm{~J}$, no inhibitor, $\alpha \mathrm{N}-0-2,15 \mathrm{~min}, 25^{\circ} \mathrm{C}$; (g) $20 \mu \mathrm{l}, \mathrm{DBA} / 2 \mathrm{~J}, 200 \mu \mathrm{M}-\mathrm{DFP}, \alpha \mathrm{N}-0-2$, $70 \mathrm{~min}, 25^{\circ} \mathrm{C}$. 
Analysis of the focussing patterns revealed a DFP-resistant esterase which had not been detected after PAGE: at pH 5.25, between Band 3 and 4 of the ES-28A cascade, a single band appeared when U-0-2 was used as substrate (Fig. 4a). This band could be identified as ES-10A which had been discovered previously in red blood cells (Peters \& Nash, 1976).

Like ES-28A, the focussing pattern of ES-28B could be demonstrated without overlapping by other esterases when ES-22 was inhibited with 1 mM-BNPP and when $\alpha \mathrm{N}-0-4$ was used as the substrate (Fig. 4d). The bands of ES-28B co-focussed exactly with those of ES-28A but their staining intensity was comparatively weak. Thus ES-28A and ES-28B appear to differ only by their activity but not by the $\mathrm{pI}$ values.

ES-28C which was present together with ES-22F in SEG/1 mice could not be demonstrated after IEF. If preinhibition by $1 \mathrm{mM}-\mathrm{BNPP}$ was omitted, ES-28C was masked by the strongly expressed bands of ES-22F. On the other hand, ES-28C turned out to be more sensitive to BNPP than ES-22F. Hence, after inhibition with BNPP, the weak bands which appeared after staining with $\alpha \mathrm{N}-0-4$ belonged to ES-22F but not to ES-28C (Fig. 4e).

In summary, our findings are that IEF, inhibition by BNPP and staining with $\alpha \mathrm{N}-0-4$ was the preferred method for distinguishing ES-28A from ES-28C. On the other hand, PAGE in combination with NASD-0-4 as a substrate was useful for distinguishing ES-28B from both ES-28A and ES-28C.

\section{Discussion}

The present results demonstrate that 11 genetically defined esterases, which were already known from investigations of other tissues or organs, can be distinguished in the cauda epididymidis of DBA/2J mice. The distribution of all these cauda esterases in liver, testis red blood cells, and serum is compiled in Table 3. Two of these enzymes, ES-1 and ES-2, have been previously identified as components of the cauda (Ruddle \& Harrington, 1967; Abou-Hailla \& Fain-Maurel, 1986). They were present in both cauda and serum. We failed, however, to detect other esterases common to cauda and serum as, for example, bands corresponding to $\mathrm{E}_{3}$ or $\mathrm{E}_{4}$ of Abou-Haïla \& Fain-Maurel (1986). The reason of this contradiction is not clear.

Table 3. Presence $(t)$ or absence $(-)$ of cauda esterases in liver, testis, red blood cells and serum of mice

\begin{tabular}{lcccc}
\hline & & \multicolumn{3}{c}{ Red blood } \\
& Liver & Testis & cells & Serum \\
\hline ES-1 & + & + & - & + \\
ES-2 & + & + & - & + \\
ES-3 & + & + & + & - \\
ES-6 & + & + & - & - \\
ES-7 & + & + & + & - \\
ES-10 & + & + & + & - \\
ES-11 & + & - & - & - \\
ES-14 & + & + & + & - \\
ES-17 & + & + & - & - \\
ES-19 & + & + & - & - \\
ES-22 & + & - & - & - \\
ES-28 & - & - & - & - \\
\hline
\end{tabular}

The 11 esterases mentioned above are classified into four categories: (1) carboxylesterase EC 3.1.1.1 (ES-1, ES-2. ES-6, ES-7, ES-11 and ES-22) constituting the major fraction of cauda esterases; (2) arylesterase EC 3.1.1.2 (ES-19); (3) acetylesterase EC 3.1.1.6 (ES-17); (4) non-classified 
esterases EC 3.1.1.X (ES-3, ES-10 and ES-14). The high concentration of ES-22 in the cauda as compared to other organs is remarkable. Only liver shows a stronger expression of ES-22 (Eisenhardt \& von Deimling, 1982). Also, ES-17 appears to be much more active in the cauda than in other organs.

Apart from these 11 esterases, 3 other enzymes reacting with $\alpha$ N-0-2, namely CDE-I, CDE-II and ES-28, were found in the cauda; these have hitherto not been genetically defined. ES-28 is thought to correspond to Band D described by Allen \& Hunter (1960) and to Band 9 described by Abou-Haila \& Fain-Maurel (1987). It showed phenotypic variation among our mouse strains: the segregation of ES-28 in backcrosses (unpublished) indicated codominant heredity of three alleles at a separate gene locus. Phenotype ES-28A appears to prevail in laboratory inbred strains. It was characterized by its high activity against butyrates and its considerable resistance to organophosphate inhibitors such as BNPP. These properties enabled us to demonstrate the 7-banded focussing pattern without any overlapping by ES-22D which is more easily inhibited.

The weakly expressed phenotype ES-28B also displayed a 7-banded focussing pattern. The single bands of ES-28B showed a precise co-focussing with the corresponding ES-28A bands. The weak activity of ES-28B could be due to a mutation in the structural gene leading to a loss of stability of the isozyme. On the other hand, the exact coincidence of the pI-values of ES-28A and ES-28B also permits assumption of a mutation in a cis-acting regulatory sequence leading to a reduced rate of biosynthesis.

The third phenotype, ES-28C, differed from the other two alloenzymes by its extremely high susceptibility to inhibition by $200 \mu \mathrm{M}$-BNPP. Such a difference could be explained, for example, by the presence of a positively charged group near the active centre of the enzyme which would facilitate the approach of the negatively charged BNPP. In this case, a mutation would have taken place in the structural gene.

ES-28 was classified as a carboxylesterase isoenzyme (EC 3.1.1.1). It was also weakly expressed in the caput epididymidis but was absent in all other organs examined. Hence, ES- 28 is the first carboxylesterase isoenzyme which is organ-specific.

We thank Mrs U. Wiehle and Mr A. Gaa for excellent technical assistance; and Dr R. Weller for valuable critique of the manuscript. Supported by the Deutsche Forschungsgemeinschaft (De 315). This is communication No. 66 of a research program devoted to the cellular distribution, regulation and genetics of non-specific esterases.

\section{References}

Abou-Haïla, A. \& Fain-Maurel, M.A. (1986) Electrophoretic characterization of mouse epididymal esterases in inbred lines and in a natural population. Andrologia 18, 624-634.

Abou-Haila, A. \& Fain-Maurel, M.A. (1987) Postnatal differentiation and endocrine control of esterase isoenzymes in the mouse epididymis. $J$. Reprod. Fert. 79, 437-446.

Allen, J.M. \& Slater, J.J. (1957) A chemical and histochemical study of alkaline phosphatase and aliesterases in the epididymis of normal and castrated mice. Anat. Rec. 129, 255-273.

Allen, J.M. \& Hunter, R.L. (1960) A histochemical study of enzymes in the epididymis of normal castrated and hormone replaced castrated mice separated by zone electrophoresis in starch gels. J. Histochem. Cytochem. 8, 50-57.

Britton-Davidian, J. \& Bonhomme, F. (1979) ES-14 et ES15 chez les souris (genre Mus L.): characterisation par differents substrats et inhibiteurs. C. r. hebd. Séanc. Acad. Sci., Paris D 288, 1419-1422.

Chapman, V., Paigen, K., Siracusa, L. \& Womack, J. (1979) Biochemical variation: mouse. In Inbred and Genetically Defined Strains of Laboratory Animals, Part 1: Mouse and Rat pp. 55-92. Eds P. L. Altman \& D. D. Katz. Federation of American Societies for Experimental Biology, Bethesda.

Eisenhardt, E. \& von Deimling, O. (1982) Interstrain variation of esterase-22, a new isozyme of the house mouse. Comp. Biochem. Physiol. 73B, 719-724.

Hilgers, J., von Deimling, O., van Zutphen, L.F.M., ten Berg, R., Anand, R. \& Festing, M.F.W. (1988) Esterase alleles of inbred mouse strains maintained in the Netherlands. Genet. Res. 51, 29-40.

Lipps, A., Ronai, A. \& von Deimling, O. (1979) Esterase7 , a conmon constituent of numerous mouse tissues. Comp. Biochem. Physiol. 62B, 201-226. 
Medda, S., von Deimling, O. \& Swank, R. (1986) Identity of esterase-22 and egasyn, the protein which complexes with microsomal $\beta$-glucuronidase. Biochem. Genet. 24, 229-243.

Münz, M. \& von Deimling, O. (1985) Electrophoretic characterization of esterase-19 (ES-19), a new arylesterase of the house mouse (Mus musculus). Electrophoresis 6, 175-178.

Nash, H.R. \& von Deimling, O. (1982) Kidney esterase of Mus musculus: further polymorphism of esterase-6, esterase-9, and a new esterase, esterase-20. Biochem. Genet. 20, 537-554.

Otto, J. \& von Deimling, O. (1983) Esterase-17 (ES-17): Characterization and linkage to chromosome 9 of a new bis-p-nitrophenyl phosphate resistant esterase of the house mouse (Mus musculus). Biochem. Genet. 21, $37-48$.

Peters, J. (1982) Nonspecific esterase of Mus musculus. Biochem. Genet. 20, 585-606.

Peters, J. \& Nash, H.R. (1976) Polymorphisms of esterase-10 in Mus musculus. Biochem. Genet. 14, 119-124.

Peters J. \& Nash, H.R. (1977) Polymorphism of esterase11 in Mus musculus, a further esterase locus on chromosome 8. Biochem. Genet. 15, 217-226.
Petras, M.L. (1963) Genetic control of a serum esterase component in Mus musculus. Proc. natn. Acad. Sci., USA 50, 112-116.

Petras, M.L. \& Sinclair, P. (1969) Another esterase variant in the kidney of the house mouse, Mus musculus. Can. J. Genet. Cytol. 11, 97-102.

Popp, R.A. \& Popp, D.M. (1962) Inheritance of serum esterases having different electrophoretic patterns. $J$. Hered. 53, 111-114.

Ruddle, F.H. \& Harrington, L. (1967) Tissue specific esterase isozymes of the mouse (Mus musculus). $J$. exp. Zool. 166, 5I-64.

Ruddle, F. \& Roderick, T. (1965) The genetic control of three kidney esterases in $\mathrm{C} 57 \mathrm{BL} / 6 \mathrm{~J}$ and $\mathrm{RF} / \mathrm{J}$ mice. Genetics, Princeton 51, 445- 454.

von Deimling, O. (1984) Mouse New's Letl. 70, 77.

von Deimling, O., Mijller, M. \& Eisenhardt, E. (1983) The non-specific esterases of mouse lung. Histochemistry 78, 271-284.

von Deimling, O., Forejt, J. \& Wienker, T.F. (1988) Allelic profile at 37 biochemical loci of two inbred strains of the house mouse derived from wild $M u s$ musculus musculus. Lab. Anim. 22, 61-66.

Received 26 January 1989 